\title{
PEMBELAJARAN BERBICARA TEKS NARASI DENGAN MENGGUNAKAN METODE PARTISIPATORI BERBASIS KECERDASAN KINESTETIK UNTUK MENINGKATKAN KETERAMPILAN BERBAHASA
}

\author{
Eny Tarsinih \\ Program Studi Pendidikan Bahasa dan Sastra Indonesia \\ Universitas Wiraalodra \\ e-mail: enytarsinih18@gmail.com
}

\begin{abstract}
ABSTRAK
Peserta didik diharapkan memiliki kemampuan untuk menangkap makna dari sebuah pesan atau informasi yang disampaikan, serta memiliki kemampuan untuk menalar dan mengemukakan kembali atau informasi yang diterimanya. Peserta didik pun diharapkan memiliki kemampuan untuk mengekspresikan berbagai pikiran, perasaan, dan pendapat serta gagasan dengan menggunakan bahasa yang baik dan benar. Kompetensi tersebut dapat dicapai melalui proses pemahiran yang dilatih dan dialami dalam kegiatan pembelajaran.

Sesuai dengan permasalahan, tujuan penelitian ini untuk meningkatkan: (1) kemampuan berbicara teks narasi sebelum menggunakan metode partisipatori berbasis kecerdasan kinestetik di kelas VII SMPN 3 Sindang; (2) kemampuan berbicara teks narasi sesudah menggunakan metode partisipatori berbasis kecerdasan kinestetik di kelas VII SMPN 3 Sindang; dan (3) efektivitas pembelajaran berbicara teks narasi dengan menggunakan metode partisipatori berbasis kecerdasan kinestetik di kelas VII SMPN 3 Sindang.

Peneliti mencoba menerapkan metode partisipatori berbasis kecerdasan kinestetik yang sesuai dengan karakteristik peserta didik kelas VII Sekolah Menegah Pertama Negeri 3 Sindang. Melalui metode ini diharapkan, peserta didik dapat terlibat penuh dan turut aktif dalam pembelajaran. Metode pembelajaran partisipatori pada umumnya menuntut peserta didik untuk terlibat secara aktif dalam kegiatan pembelajaran dengan berpikir dan berbuat secara aktif, bebas, terbuka, dan bertanggung jawab dalam hal mempelajari hal-hal yang bermakna untuk memenuhi kebutuhan belajar dan kepentingan bersama (Sudjana, 2010: 51). Oleh karena itu, peserta didik diharapkan terlibat aktif dalam mempraktikkan dan melatih lebih
\end{abstract}


lagi keterampilan berbicara teks narasi dengan awalnya menggunakan teknik membaca sastra yaitu membaca legenda tokoh Arya Wiralodra yang disediakan oleh peneliti. Kemudian peserta didik dan peneliti melaksanakan kegiatan pembelajaran dengan menerapkan tahapan dalam metode partisipatori. Setelah itu peserta didik menceritakan kembali dengan melibatkan anggota tubuh sebagai alat untuk mengekspresikan sesuai dengan apa yang dibaca dari legenda tokoh tersebut.

Hasil penelitian ini diharapkan dapat memberikan beberapa manfaat baik secara teoretis maupun praktis, yaitu: (1) memberikan acuan terhadap perkembangan kecerdasan kinestetik, khususnya kemampuan berbicara siswa; (2) mengetahui metode yang tepat dalam meningkatkan kemampuan berbicara siswa dan memperoleh pengalaman belajar yang menarik; (3) menambah wawasan dan pengalaman peneliti untuk mengembangkan ilmu pengetahuan, khususnya dalam bidang pendidikan; dan (4) bagi lembaga, dapat dijadikan masukan untuk membangun dan meningkatkan kualitas pendidikan.

Berdasarkan tujuan yang akan dicapai, target luaran yang diharapkan dapat diperoleh sebagai dampak dari penelitian ini dapat dijabarkan sebagai berikut. (1) Dapat memperkuat riset dosen dalam bidang pendidikan bahasa Indonesia khususnya mengenai pembelajaran bahasa Indonesia berbasis kinestetik melalui metode partisipatori. (2) Bahan ajar yang digunakan dalam penelitian ini diharapkan dapat menjadi inspirasi bagi guru dalam membuat bahan ajar berbasis kinestetik melalui metode partisipatori.

\section{Kata kunci: Berbicara, Teks Narasi, Partisipatori, dan Kinestetik}

\section{A. PENDAHULUAN}

Manusia tidak pernah lepas dari aktivitas berbahasa dalam kehidupan seharihari. Bahasa digunakan seseorang sebagai alat komunikasi antarsesamanya. Kegiatan komunikasi tersebut merupakan salah satu bentuk aktivitas seseorang sebagai makhluk sosial. Dengan kata lain, bahasa memegang peranan yang sangat penting dalam berkomunikasi.
Semakin berkembangnya ilmu pengetahuan dan teknologi seharusnya ditunjang oleh kemampuan pemanfaatan, pengembangan, dan penguasaan ilmu terapan maupun ilmu pengetahuan dasar secara seimbang. Salah satu usaha untuk meningkatkan penguasaan pengetahuan dasar adalah dengan meningkatkan keterampilan berbahasa. Ruang lingkup pembelajaran bahasa Indonesia antara lain terdapat aspek kemampuan berbahasa yang meliputi aspek 
mendengarkan, menyimak, berbicara, itu keterampilan berbicara dianggap sebagai membaca, dan menulis. salah satu keterampilan yang menjadi ukuran

Melalui pembelajaran bahasa Indonesia, peserta didik diharapkan memiliki kemampuan untuk menangkap makna dari sebuah pesan atau informasi yang disampaikan, serta memiliki kemampuan untuk menalar dan mengemukakan kembali atau informasi yang diterimanya. Peserta didik pun diharapkan memiliki kemampuan untuk mengekspresikan berbagai pikiran, perasaan, dan pendapat serta gagasan dengan menggunakan bahasa baik. Kompetensi tersebut dapat dicapai melalui proses pemahiran yang dilatih dan dialami dalam kegiatan pembelajaran.

Pembelajaran bahasa dan sastra Indonesia pada hakikatnya bertujuan untuk mengajarkan, melatih, dan mengarahkan peserta didik dalam berbahasa dan berinteraksi dalam masyarakat. Melalui interaksi tersebut, peserta didik dapat berkomunikasi melalui bahasa Indonesia yang baik dan benar. Dengan kata lain, secara tidak langsung pembelajaran bahasa Indonesia mengharapkan peserta didik terampil dalam berbahasa baik lisan maupun tulisan.

Salah satu aspek keterampilan berbahasa yang berkaitan dengan pengungkapan pikiran, gagasan, dan pendapat tersebut adalah keterampilan berbicara. Selain dalam membandingkan kualitas kemampuan seseorang. Kemampuan seseorang yang kualitasnya akan lebih mudah terlihat melalui caranya berbicara. Oleh karean itu, melatih keterampilan berbicara berarti pula melatih keterampilan berpikir. Maka dalam pembelajaran berbicara di sekolah, peserta didik diharapkan tidak hanya mampu mengusai dan menghafal teori yang mereka pelajari, tetapi juga memiliki kemampuan bahasa sebagaimana tujuan utamanya, dalam hal ini berbicara dapat digunakan untuk mengasah keterampilan peserta didik.

Melalui observasi awal terhadap peserta didik di sekolah, tidak sedikit peserta didik yang belum mau mengungkapkan ide dan mengekspresikan gagasannya karena merasa tidak percaya diri dan takut mengalami kesalahan, serta masih banyak peserta didik yang belum berani untuk terlibat aktif dalam pembelajaran yang sedang berlangsung, khususnya pada pembelajaran keterampilan berbicara.

Meninjau dari hal tersebut, alangkah baiknya jika terdapat metode atau sarana yang tepat untuk memperbaiki proses pembelajaran keterampilan berbicara peserta didik. Maka dibutuhkan metode pembelajaran yang mampu melibatkan peserta didik secara aktif dan turut berpartisipasi dalam pembelajaran. 
Peneliti mencoba menerapkan metode pembelajaran keterampilan berbicara yang sesuai dengan karakteristik peserta didik kelas tujuh Sekolah Menegah Pertama yang belum baik keterampilan berbicaranya. Metode pembelajaran yang akan peneliti terapkan adalah metode partisipatori yang berbasis kecerdasan kinestetik untuk meningkatkan keterampilan berbicara peserta didik.

Melalui metode partisipatori yang berbasis kecerdasan kinestetik ini diharapkan, peserta didik dapat terlibat penuh dan turut aktif dalam pembelajaran. Metode pembelajaran partisipatori pada umumnya menuntut peserta didik untuk terlibat secara aktif dalam kegiatan pembelajaran dengan berpikir dan berbuat secara aktif, bebas, terbuka, dan bertanggung jawab dalam hal mempelajari hal-hal yang bermakna untuk memenuhi kebutuhan belajar dan kepentingan bersama (Sudjana, 2010: 51). Oleh karena itu, peserta didik diharapkan terlibat aktif dalam mempraktikkan dan melatih lebih lagi keterampilan berbicaranya dengan awalnya menggunakan teknik membaca sastra yaitu membaca legenda tokoh Arya Wiralodra yang disediakan oleh peneliti. Kemudian peserta didik dan peneliti melaksanakan kegiatan pembelajaran dengan menerapkan tahapan dalam metode partisipatori. Setelah itu peserta didik menceritakan kembali dengan melibatkan anggota tubuh sebagai alat untuk mengekspresikan sesuai dengan apa yang dibaca dari legenda tokoh tersebut.

Pembelajaran bahasa Indonesia yang berbasis kecerdasan kinestetik dengan menggunakan metode partisipatori ini merupakan metode yang melibatkan peran peserta didik secara aktif dengan menggunakan seluruh tubuh untuk mengekspresikan ide dan perasaannya dalam proses belajar mengajar. Kecerdasan kinestetik merupakan salah satu kecerdasan dalam kecerdasan majemuk (multiple intelligence). Oleh karena itu, metode ini diharapkan dapat membantu peserta didik dalam mengembangkan atau meningkatkan keterampilannya dalam berbicara.

\section{B. METODE PENELITIAN}

Berdasarkan latar belakang penelitian, metode yang dianggap tepat untuk peneltian ini adalah metode penelitian studi eksperimen. Dalam studi eksperimen, pengukuran kemampuan berbicara peserta didik dilakukan sebelum dan sesudah sampel penelitian diberi perlakuan dengan metode partisipatori yang berbasis kecerdasan kinestetik dalam bentuk mengekspresikan dan menceritakan kembali legenda tokoh. Pengukuran yang dilakukan sebelum perlakuan disebut tes awal, sedangkan pengukuran sesudah perlakuan disebut tes akhir. Desain rancangan yang dipakai dalam penelitian ini adalah Pretest-posttest Control 
Group Design. Penelitian yang dilakukan sebelum eksperimen $\left(\mathrm{O}_{1}\right)$ disebut pretest, dan sesudah eksperimen $\left(\mathrm{O}_{2}\right)$ disebut posttest. Perbedaan antara $\mathrm{O}_{1}$ dan $\mathrm{O}_{2}$ yakni $\mathrm{O}_{2}-\mathrm{O}_{1}$ diasumsikan merupakan efek dari treatment atau perlakuan metode partisipatori berbasis kecerdasan kinestetik.$$
\mathrm{O}_{1} \mathrm{XO}_{2}
$$

Keterangan:

$\mathrm{O}_{1}$ : Observasi pertama (tes awal) dilakukan sebelum menggunakan metode partisipatori berbasis kecerdasan kinestetik.

X: Perlakuan yaitu pembelajaran berbicara teks narasi menggunakan metode partisipatori berbasis kecerdasan kinestetik.

$\mathrm{O}_{2}$ : Observasi kedua (tes akhir) dilakukan sesudah menggunakan metode partisipatori berbasis kecerdasan kinestetik.

\section{Instrumen Penelitian}

Instrumen Penelitian yang digunakan dalam penelitian ini yaitu tes. Instrumen berupa tes kemampuan berbicara dengan berpedoman pada pedoman penilaian. Tes dilakukan dengan memberikan tes pada objek penelitian yaitu siswa kelas VII SMP Negeri 3 Sindang untuk mengetahui kemampuan berbicara siswa dengan metode partisipatori yang berbasis kecerdasan kinestetik.

\section{Teknik Penelitian}

\section{a. Teknik Pengumpulan Data}

Teknik pengumpulan data dalam penelitian ini adalah dengan tes hasil belajar. Teknik tes yang digunakan ada dua, yaitu:

\section{1) Pre-test atau tes awal}

Pengumpulan data dengan cara melaksanakan kegiatan belajar sebelum menggunakan metode partisipatori yang berbasis kecerdasan kinestetik. Hasil tes yang dijadikan data penelitian berupa kemampuan berbicara siswa.

2) Post-test atau tes akhir

Pengumpulan data dengan cara melaksanakan kegiatan belajar sesudah menggunakan metode partisipatori yang berbasis kecerdasan kinestetik. Hasil tes yang dijadikan data penelitian berupa kemampuan berbicara siswa dalam menceritakan kembali cerita rakyat/dongeng dengan gerak-gerik yang diperagakan.

Melalui pembelajaran pre-test dan post-test peneliti dapat mengetahui adanya perbedaan hasil pembelajaran kemampuan berbicara sebelum dan sesudah menggunakan metode partisipatori yang berbasis kecerdasan kinestetik. 


\section{b. Teknik Pengolahan Data}

Terdapat dua bentuk data yang akan diolah pada penelitian ini, antara lain data proses dan hasil data. Data proses dapat dianalisis melalui angket, observasi, dan wawancara. Data hasil belajar pada penelitian ini berupa data hasil tes keterampilan berbicara melalui tes awal dan tes akhir.

$$
t_{\text {hitung }}=\frac{M d}{\sqrt{\frac{\Sigma x^{2} d}{N(N-1)}}}
$$

Keterangan:

Md = Mean dari deviasi (d) antara post-test dan pre-test

$\mathrm{N} \quad=$ Banyaknya subjek pada sampel

d.b = Ditentukan dengan N-1

$\sum \mathrm{x}^{2} \mathrm{~d}=$ Jumlah kuadrat deviasi

\section{HASIL PENELITIAN}

Berbicara merupakan salah satu keterampilan berbahasa dalam kehidupan sehari-hari. Seseorang lebih sering memilih berbicara untuk berkomunikasi, karena komunikasi lebih efektif jika dilakukan dengan berbicara. Berbicara memegang peranan penting dalam kehidupan sehari-hari. Pembelajaran bahasa Indonesia yang berbasis kecerdasan kinestetik dengan menggunakan metode partisipatori ini merupakan metode yang melibatkan peran peserta didik secara aktif dengan menggunakan seluruh tubuh untuk mengekspresikan ide dan perasaannya dalam proses belajar mengajar. Kecerdasan kinestetik merupakan salah satu kecerdasan dalam kecerdasan majemuk (multiple intelligence). Oleh karena itu, metode ini diharapkan dapat membantu peserta didik dalam mengembangkan atau meningkatkan keterampilannya dalam berbicara.

Penelitian ini dilaksanakan di kelas VII SMP Negeri 3 Sindang tahun pelajaran 2018/2019 yang dilaksanakan sejak tanggal 23-24 Juli 2019. Pelaksanaan pembelajaran berlangsung 4 x 40 menit.

\section{Pelaksanaan Pembelajaran Berbicara Teks Narasi dengan Menggunakan} Metode Partisipatori Berbasis Kecerdasan Kinestetik

Pembelajaran berbicara teks narasi dengan menggunakan metode partisipatori berbasis kecerdasan kinestetik dengan alokasi waktu 4 x 40 menit. Ada tiga tahapan yang dilakukan dalam pembelajaran ini, yaitu kegiatan awal, kegiatan inti, dan kegiatan akhir.

Di bawah ini penulis laporkan pelaksanaan pembelajaran berbicara teks narasi dengan menggunakan metode partisipatori berbasis kecerdasan kinestetik tahun pelajaran 2018/2019.

Hari Selasa, 23 Juli 2019 
Pukul 07.00-08.30 WIB

Kelas VII-F

\section{a) Kegiatan Awal}

Kegiatan awal dilakukan sebelum pembelajaran dimulai. Kegiatan ini diisi dengan mengadakan perkenalan, memberi apersepsi dan motivasi, menyampaikan kompetensi inti dan kompetensi dasar (KI$\mathrm{KD})$, tujuan pembelajaran, serta melaksanakan pre-test.

\section{(1) Perkenalan}

Perkenalan dilakukan supaya terjalin keakraban antara guru, penulis, dan siswa, sehingga kegiatan pembelajaran dapat dilaksanakan dengan lebih efektif. Di bawah ini adalah dialog antara guru Bahasa Indonesia, penulis (peneliti), dan siswa (responden).

(Guru Bahasa Indonesia dan penulis masuk ke kelas VII-F)

Guru

Assalammualaikumwarahmatullahiwabaraka tuh.

\section{Siswa}

Waalaikumsalamwarahmatullahiwabarakatu h.

Guru : Silakan mengaji terlebih dahulu (10 menit).

Siswa : (mengaji)

Guru : Silakan disiapkan oleh KM
Siswa (KM) : Sebelum belajar, marilah kita berdoa. Berdoa mulai!

(setelah berdoa) Beri salam!

Siswa

Assalammualaikumwarahmatullahiwabaraka tuh.

Guru

Waalaikumsalamwarahmatullahiwabarakatu h.

Hari ini hadir semua?

Siswa $\quad$ : Hadir, Bu.

Guru : Bagus. Baiklah anak-anak sekarang kalian kedatangan tamu yaitu Ibu Eny, yang akan menggantikan ibu untuk pertemuan hari ini. Kalian siap?

Siswa : Siap, Bu.

Guru : Selamat belajar. Silakan Bu Eny!

Penulis : Terima kasih, Ibu.

Guru : : Sama-sama.

(Guru Bahasa Indonesia keluar dari kelas VII-F)

Penulis

Assalammualaikumwarahma tullahiwabarakatuh.

Siswa

Waalaikumsalamwarahmatul lahiwabarakatuh.

(Ketua Murid). 
Penulis $\quad$ : Perkenalkan nama saya, Eny

Tarsinih, M.Pd., dari

Universitas Wiralodra.

Terima kasih sudah bersedia membantu saya dalam penelitian ini.

Siswa : Sama-sama, Bu.

Penulis : Saya akan mendata daftar hadir terlebih dahulu supaya tahu nama-nama kalian. Hadir semua kan?

Siswa $\quad$ : Iya, Bu.

\section{(2) Apersepsi dan Motivasi}

Penulis

: Pembelajaran merupakan suatu proses yang harus kita lalui dalam kehidupan ini, karena dengan belajar kita bisa berubah menjadi lebih baik. Kemarin baru saja kakak kelas kalian mengikuti $\mathrm{UN}$, tentu yang kita harapkan adalah lulus $100 \%$.

Siswa

: Aamiin...

Penulis

: Tetapi jangan hanya hasil akhir saja yang dipentingkan, proses adalah hal yang utama, yaitu bagaimana cara memperoleh hasil tersebut. Kalian sudah melaksanakan UAS (Ujian

Akhir Semester)?

Siswa : Sudah, Bu.
Penulis : Kalian jangan terbebani oleh nilai karena hanya bersifat normatif.

Pepatah mengatakan bersakit-sakit dahulu, bersenang-senang kemudian. Kesuksesan itu bisa didapat dari bagaimana cara kita mengusahakannya, kalau mau sukses tentu harus berusaha dan giat belajar. Pesan saya, jangan sekalikali mencontek kalau tidak mau merugi di kemudian hari, karena hanya akan menanamkan sifat buruk dalam diri kita.

: Ya, Bu.

: Ada yang bisa menjelaskan, apa itu cerita rakyat?

Siswa

: Saya, Bu. (sambil mengacungkan tangan)

Penulis : Ya, silakan.

Siswa : Cerita dari rakyat, Bu.

Penulis : Ada lagi yang mau menjawab?

Siswa

: Saya, Bu. (sambil mengacungkan tangan)

Penulis : Ya, silakan.

Siswa

: Cerita rakyat adalah cerita daerah dari masyarakat setempat.

Penulis menyempurnakan? 
BAHTERA INDONESIA:

Jurnal Penelitian Pendidikan Bahasa dan Sastra Indonesia

Siswa

$$
\begin{aligned}
& \text { : Saya, Bu. Saya. Saya. (saling } \\
& \text { berebut menjawab } \\
& \text { pertanyaan) }
\end{aligned}
$$

Penulis $\quad$ : Ya silakan yang duduk di sudut kanan.

Siswa

: Cerita rakyat merupakan cerita yang berasal dari masyarakat dan berkembang dalam masyarakat pada masa lampau.

Penulis : Ya, tepat sekali jawabannya.

\section{(3) KI-KD}

Penulis

: Baiklah sekarang materinya cerita rakyat.

KI-1 menghargai dan menghayati ajaran agama yang dianutnya.

KI-2 menghargai dan menghayati perilaku jujur, disiplin, tanggung jawab, peduli (toleransi, gotong royong), santun, percaya diri, dalam berinteraksi secara efektif dengan lingkungan sosial dan alam dalam jangkauan pergaulan dan keberadaannya.

KI-3 memahami pengetahuan (faktual, konseptual, prosedural, dan metakognitif) berdasarkan adalah:
ISSN 2541-3252

Vol. 4, No. 2, Sep. 2019

rasa ingin tahunya tentang ilmu pengetahuan, teknologi, seni, budaya terkait fenomena dan kejadian tampak mata.

KI-4 mencoba, mengolah, dan menyaji dalam ranah konkret (menggunakan, mengurai, merangkai, memodifikasi, dan membuat) dan ranah abstrak (menulis, membaca, menghitung, menggambar, dan mengarang) sesuai dengan yang dipelajari di sekolah dan sumber lain yang sama dalam sudut pandang/teori.

Kompetensi dasarnya yaitu menceritakan kembali isi cerita rakyat (legenda) daerah setempat.

\section{(4) Tujuan Pembelajaran}

Penulis : Tujuan pembelajarannya

1) siswa mampu mencermati cerita rakyat (legenda) yang berasal dari daerah setempat dengan benar;

2) siswa mampu berlatih menceritakan isi cerita 


rakyat (legenda) yang
dibaca dengan benar; dan
siswa mampu
menceritakan kembali isi
cerita rakyat (legenda)
yang dibaca dengan
benar.

(5) Melaksanakan Pre-test

Penulis : Baiklah kalau kalian sudah mengerti, saya harap kalian bisa bersungguh-sungguh menjalankan pesan saya tadi. Sekarang sebelum pembelajaran dimulai, ada pre-test atau tes awal untuk menguji seberapa jauh kalian mengetahui cerita rakyat "Babad Dermayu".

Siswa : Maju satu-satu, Bu?

Penulis : Iya. (menyebutkan nama satu per satu)

\section{b) Kegiatan Inti}

Dalam kegiatan ini, penulis menjelaskan ciri cerita rakyat (legenda), langkah memahami isi cerita rakyat (legenda), dan langkah menceritakan kembali isi cerita rakyat (legenda).

Penulis : Cerita rakyat merupakan cerita yang berasal dan berkembang dari masyarakat pada masa lampau dan menjadi ciri khas tiap-tiap bangsa yang mempunyai budaya yang beraneka ragam melingkupi kekayaan budaya serta sejarah yang dimiliki oleh tiap bangsa. Ciri-ciri cerita rakyat, yaitu:

a. disampaikan secara turuntemurun;

b. tak diketahui secara pasti siapa yang pertama kali membuatnya;

c. kaya akan nilai-nilai luhur;

d. bersifat tradisional;

e. mempunyai banyak versi dan variasi; dan

f. memiliki bentuk-bentuk yang klise baik dalam susunan atau dalam cara pengungkapannya.

Penulis : Silakan baca terlebih dahulu teks cerita rakyat "Babad Dermayu".

Siswa : Terus dihafalin, Bu?

Penulis : Iya. Lalu ceritakan kembali ya di depan kelas dengan gerakan secara ekspresif!

Siswa

: Sambil duduk di bangku saja sih, Bu?

Penulis : Tidak boleh. Belajar berbicara di depan kelas ya? Nanti Ibu contohkan gerakannya. 
BAHTERA INDONESIA:

Jurnal Penelitian Pendidikan Bahasa dan Sastra Indonesia

Siswa

: Iya, Bu.

Hari Rabu, 24 Juli 2019

Pukul 07.00-08.30 WIB

Kelas VII-F

\section{c) Kegiatan Akhir}

Pada bagian ini penulis melakukan evaluasi, penguatan, dan melaksanakan posttest.

Penulis : Sekarang jelaskan kembali apa itu cerita rakyat?

$\begin{array}{ll}\text { Siswa } & \text { : Saya, Bu. } \\ \text { Penulis } & \text { : Ya, silakan! } \\ \text { Siswa } & : \text { Cerita rakyat merupakan } \\ & \text { cerita yang berasal dan } \\ & \text { berkembang dari masyarakat } \\ & \text { pada masa lampau dan } \\ & \text { menjadi ciri khas tiap-tiap } \\ & \text { bangsa. }\end{array}$

Penulis : Tepat sekali. Lihat catatan ya?

Siswa : Tidak kok, Bu.

Penulis : Lalu ciri-ciri cerita rakyat bagaimana?

Siswa : Saya, Bu.

Penulis : Silakan!

Siswa : Cirinya adalah:

a. disampaikan secara turuntemurun;
ISSN 2541-3252

Vol. 4, No. 2, Sep. 2019 b. tak diketahui secara pasti siapa yang pertama kali membuatnya;

c. kaya akan nilai-nilai luhur;

d. bersifat tradisional;

e. mempunyai banyak versi dan variasi; dan

f. memiliki bentuk-bentuk yang klise baik dalam susunan atau dalam cara pengungkapannya.

Penulis : Bagus, sudah mengerti semua. Baiklah sekarang kita lakukan post-test atau tes akhir. Jangan lupa ketika menceritakan ulang harus disertai dengan gerakan ya? Ketika Raden Arya Wiralodra berkelahi dengan Nyi Endang Dharma tunjukkan jurus-jurusnya dengan gerakan imajinasi kalian. Paham?

: Paham, Bu.

Penulis : : (menyebutkan nama satu per satu)

Baiklah kalian sudah menunjukkan kemampuan secara maksimal, maka saya akan beri hadiah.

Siswa : Apa, Bu? 
Penulis : Jajan rame-rame. Ibu yang traktir.

Siswa

: Hore... sering-sering ke sini,

$\mathrm{Bu}$ ?

Penulis

: Tidak mau ah, nanti tekor.

Hehehe... Terima kasih ya atas perhatian dan bantuan kalian semua. Saya akhiri, wassalammualaikumwarahm atullahiwabarakatuh.

Siswa

Waalaikumsalamwarahm atullahiwabarakatuh.

\section{Berbicara Teks Narasi Sebelum} Menggunakan Metode Partisipatori Berbasis Kecerdasan Kinestetik

Kemampuan siswa kelas VII SMP Negeri 3 Sindang dalam pembelajaran berbicara teks narasi sebelum menggunakan metode partisipatori berbasis kecerdasan kinestetik tahun pelajaran 2018/2019 menggunakan data berskala ordinal, supaya memperoleh data yang akurat dan relevan dengan masalah yang diteliti. Untuk analisis secara kuantitatif, jawaban tertinggi diberi skor 5 dan terendah diberi skor 1. Adapun unsur yang dinilai dalam pembelajaran

2. Kemampuan Siswa Kelas VII SMP berbicara teks narasi sebagai berikut. Negeri 3 Sindang Tahun Pelajaran 2018/2019 dalam Pembelajaran

Tabel 1. Unsur yang Dinilai dalam Pembelajaran Berbicara Teks Narasi

\begin{tabular}{|c|l|c|c|c|c|c|}
\hline \multirow{2}{*}{ NO. UNSUR YANG DINILAI } & \multicolumn{5}{c|}{ SKOR } \\
\cline { 3 - 7 } & & $\mathbf{1}$ & $\mathbf{2}$ & $\mathbf{3}$ & $\mathbf{4}$ & $\mathbf{5}$ \\
\hline 1. & Kesesuaian isi cerita & & & & & \\
\hline 2. & Ekspresi wajah & & & & & \\
\hline 3. & Penggunaan Bahasa & & & & & \\
\hline 4. & Gerakan & & & & & \\
\hline 5. & Ucapan & & & & & \\
\hline 6. & Intonasi & & & & & \\
\hline 7. & Pengaturan jeda & & & & & \\
\hline 8. & Intensitas dan kelancaran berbicara & & & & & \\
\hline 9. & Diksi yang digunakan & & & & & \\
\hline 10. & Sistematika & & & & & \\
\hline & & & & & \\
\hline
\end{tabular}




$$
\text { Nilai }=\frac{\text { Skor yang diperoleh }}{\text { Skor maksimal }} \times 100
$$

Tabel 2. Konversi Nilai (kuantitatif-kualitatif)

\begin{tabular}{|l|c|}
\hline \multicolumn{1}{|c|}{ Nilai } & Kategori \\
\hline $85-100$ & Sangat Baik \\
\hline $75-84$ & Baik \\
\hline $60-74$ & Cukup \\
\hline $40-59$ & Kurang \\
\hline $0-39$ & Gagal \\
\hline
\end{tabular}

(Nurgiyantoro, 2001: 399)

Berikut ini penulis sajikan uraian kemampuan siswa kelas VII SMP Negeri 3 Sindang tahun pelajaran 2018/2019 dalam pembelajaran berbicara teks narasi sebelum menggunakan metode partisipatori berbasis kecerdasan kinestetik.

Tabel 3. Nilai Siswa Sebelum Pembelajaran dengan Menggunakan Metode Partisipatori Berbasis Kecerdasan Kinestetik

\begin{tabular}{|c|c|c|}
\hline No. & Nama Siswa & Pre-test \\
& & $(\mathrm{X})$ \\
\hline
\end{tabular}

\begin{tabular}{|l|l|c|}
\hline 1. & Ahmad Dani & 34 \\
\hline 2. & Carudin & 44 \\
\hline 3. & Castana & 48 \\
\hline 4. & Chamelia & 38 \\
\hline 5. & Dian Lestari & 28 \\
\hline 6. & $\begin{array}{l}\text { Dini Ramdani } \\
\text { Oktiawati }\end{array}$ & 30 \\
\hline 7. & Fitriyani & 56 \\
\hline 8. & Khaerul Sobirin & 36 \\
\hline 9. & Kiswah Azizah & 32 \\
\hline 10. & Kristina & 34 \\
\hline 11. & Lusi Indriyani & 36 \\
\hline 12. & Meli Ratnawati & 42 \\
\hline 13. & Nani Mealifah & 40 \\
\hline 14. & Rahayuda Trisukma & 24 \\
\hline 15. & Rasudi & 44 \\
\hline 16. & $\begin{array}{l}\text { Regita } \\
\text { Rusyani }\end{array}$ & 38 \\
\hline 17. & Risqy Langit & 36 \\
\hline 18. & Tias Ramadhani & 40 \\
\hline 19. & Tukiman & 46 \\
\hline 20. & Vika Lestari & 50 \\
\hline 21. & Zahra Rifatul Istiqna & \\
\hline & \multicolumn{1}{|c|}{ N = 21 } & \\
\hline
\end{tabular}

3. Kemampuan Siswa Kelas VII SMP Negeri 3 Sindang Tahun Pelajaran 2018/2019 dalam Pembelajaran Berbicara Teks Narasi Sesudah Menggunakan Metode Partisipatori Berbasis Kecerdasan Kinestetik 
Kemampuan siswa kelas VII SMP Negeri 3 Sindang dalam pembelajaran berbicara teks narasi sesudah menggunakan metode partisipatori berbasis kecerdasan kinestetik tahun pelajaran 2018/2019 menggunakan data berskala ordinal, supaya memperoleh data yang akurat dan relevan dengan masalah yang diteliti. Untuk analisis secara kuantitatif, jawaban tertinggi diberi skor 5 dan terendah diberi skor 1 .

Berikut ini penulis sajikan uraian kemampuan siswa kelas VII SMP Negeri 3 Sindang tahun pelajaran 2018/2019 dalam pembelajaran berbicara teks narasi sesudah menggunakan metode partisipatori berbasis kecerdasan kinestetik.

\section{Tabel 4. Nilai Siswa Sesudah Pembelajaran dengan Menggunakan Metode Partisipatori Berbasis}

Kecerdasan Kinestetik

\begin{tabular}{|l|l|c|}
\hline No. & \multicolumn{1}{|c|}{ Nama Siswa } & $\begin{array}{c}\text { Post-test } \\
(\mathbf{Y})\end{array}$ \\
\hline 1. & Ahmad Dani & 76 \\
\hline 2. & Carudin & 74 \\
\hline 3. & Castana & 76 \\
\hline 4. & Chamelia & 82 \\
\hline 5. & Dian Lestari & 72 \\
\hline 6. & $\begin{array}{l}\text { Dini Ramdani } \\
\text { Oktiawati }\end{array}$ & 82 \\
\hline 7. & Fitriyani & 88 \\
\hline 8. & Khaerul Sobirin & 76 \\
\hline
\end{tabular}

\begin{tabular}{|l|l|c|}
\hline 9. & Kiswah Azizah & 90 \\
\hline 10. & Kristina & 78 \\
\hline 11. & Lusi Indriyani & 84 \\
\hline 12. & Meli Ratnawati & 84 \\
\hline 13. & Nani Mealifah & 80 \\
\hline 14. & Rahayuda Trisukma & 78 \\
\hline 15. & Rasudi & 78 \\
\hline 16. & Regita & 62 \\
\hline 17. & Risqy Langit & 70 \\
\hline 18. & Tias Ramadhani & 70 \\
\hline 19. & Tukiman & 78 \\
\hline 20. & Vika Lestari & 64 \\
\hline 21. & Zahra Rifatul Istiqna & 84 \\
\hline & N = 21 & 1626 \\
\hline
\end{tabular}

4. Efektivitas Pembelajaran Berbicara Teks Narasi dengan Menggunakan Metode Partisipatori Berbasis Kecerdasan Kinestetik di Kelas VII SMP Negeri 3 Sindang Tahun

\section{Pelajaran 2018/2019}

Efektif atau tidaknya sebuah pembelajaran harus dibuktikan secara ilmiah, bukan hanya berdasarkan spekulasi sepihak dari seseorang yang berkepentingan. Pembahasan sub judul ini adalah dalam rangka membuktikan asumsi penulis berdasarkan standar penghitungan uji-t.

Di bawah ini adalah tabel nilai siswa dalam pembelajaran berbicara teks narasi dengan menggunakan metode partisipatori berbasis kecerdasan kinestetik antara sebelum 
dan sesudah pembelajaran. Untuk menghitung efektivitas antara pre-test dan post-test, dibuat tabel penghitungan untuk memperoleh " $t$ ".

Tabel 5. Tabel Penghitungan Pretest dan Post-test untuk Memperoleh “t'" dalam Mencari Efektivitas Metode Partisipatori Berbasis Kecerdasan Kinestetik

\begin{tabular}{|c|c|c|c|c|}
\hline \multirow[b]{2}{*}{ No. } & \multirow[b]{2}{*}{$\begin{array}{l}\text { Nama } \\
\text { Siswa }\end{array}$} & \multicolumn{2}{|c|}{ Nilai Siswa } & \multirow[b]{2}{*}{$\begin{array}{l}\mathbf{d}= \\
(\mathrm{Y}- \\
\mathbf{X})\end{array}$} \\
\hline & & $\begin{array}{l}\text { Pre- } \\
\text { test } \\
(\mathrm{X})\end{array}$ & $\begin{array}{l}\text { Post- } \\
\text { test } \\
(\mathrm{Y})\end{array}$ & \\
\hline 1. & $\begin{array}{l}\text { Ahmad } \\
\text { Dani }\end{array}$ & 34 & 76 & 42 \\
\hline 2. & Carudin & 44 & 74 & 30 \\
\hline 3. & Castana & 48 & 76 & 28 \\
\hline 4. & Chamelia & 38 & 82 & 44 \\
\hline 5. & Dian Lestari & 28 & 72 & 44 \\
\hline 6. & $\begin{array}{l}\text { Dini } \\
\text { Ramdani } \\
\text { Oktiawati }\end{array}$ & 30 & 82 & 52 \\
\hline 7. & Fitriyani & 56 & 88 & 32 \\
\hline 8. & $\begin{array}{l}\text { Khaerul } \\
\text { Sobirin }\end{array}$ & 36 & 76 & 40 \\
\hline 9. & $\begin{array}{l}\text { Kiswah } \\
\text { Azizah }\end{array}$ & 32 & 90 & 58 \\
\hline 10 & Kristina & 34 & 78 & 44 \\
\hline
\end{tabular}

\begin{tabular}{|c|c|c|c|c|}
\hline 11. & $\begin{array}{l}\text { Lusi } \\
\text { Indriyani }\end{array}$ & 36 & 84 & 48 \\
\hline 12. & $\begin{array}{l}\text { Meli } \\
\text { Ratnawati }\end{array}$ & 42 & 84 & 42 \\
\hline 13. & $\begin{array}{l}\text { Nani } \\
\text { Mealifah }\end{array}$ & 40 & 80 & 40 \\
\hline 14. & $\begin{array}{l}\text { Rahayuda } \\
\text { Trisukma }\end{array}$ & 24 & 78 & 54 \\
\hline 15 . & Rasudi & 44 & 78 & 34 \\
\hline 16. & $\begin{array}{l}\text { Regita } \\
\text { Indah } \\
\text { Rusyani }\end{array}$ & 38 & 62 & 24 \\
\hline 17. & $\begin{array}{l}\text { Risqy } \\
\text { Langit }\end{array}$ & 36 & 70 & 34 \\
\hline 18. & $\begin{array}{l}\text { Tias } \\
\text { Ramadhani }\end{array}$ & 40 & 70 & 30 \\
\hline 19. & Tukiman & 46 & 78 & 32 \\
\hline 20. & Vika Lestari & 28 & 64 & 36 \\
\hline 21. & $\begin{array}{l}\text { Zahra } \\
\text { Rifatul } \\
\text { Istiqna }\end{array}$ & 50 & 84 & 34 \\
\hline & $\mathrm{N}=21$ & & & 822 \\
\hline
\end{tabular}

Tabel 6. Tabel Penghitungan Jumlah Kuadrat Deviasi untuk Memperoleh "t'" dalam Mencari Efektivitas Metode Partisipatori Berbasis Kecerdasan Kinestetik 


\begin{tabular}{|c|c|c|c|c|c|c|c|c|c|}
\hline \multirow[t]{2}{*}{ No } & \multirow[t]{2}{*}{$\begin{array}{l}\text { Nama } \\
\text { Siswa }\end{array}$} & \multirow[t]{2}{*}{$\begin{array}{l}\mathbf{d}^{2}= \\
(Y- \\
X)^{2}\end{array}$} & \multirow{2}{*}{$\begin{array}{c}\text { Xd } \\
= \\
\text { (d- } \\
\text { Md) }\end{array}$} & \multirow[t]{2}{*}{$X d^{2}$} & 14. & $\begin{array}{l}\text { Rahayud } \\
\text { a } \\
\text { Trisukma }\end{array}$ & 2916 & $\begin{array}{c}14,8 \\
6\end{array}$ & $\begin{array}{c}220,819 \\
6\end{array}$ \\
\hline & & & & & 15. & Rasudi & 1156 & - & 264106 \\
\hline \multirow[t]{2}{*}{1.} & Ahmad & \multirow{2}{*}{1764} & \multirow{2}{*}{2,86} & \multirow{2}{*}{8,1796} & & & 1700 & 5,14 & ש \\
\hline & Dani & & & & \multirow[t]{2}{*}{16.} & \multirow{2}{*}{$\begin{array}{l}\text { Regita } \\
\text { Indah } \\
\text { Rusyani }\end{array}$} & \multirow[b]{2}{*}{576} & - & \multirow{2}{*}{$\begin{array}{c}229,219 \\
6\end{array}$} \\
\hline 2. & Carudin & 900 & $\begin{array}{c}- \\
9,14\end{array}$ & 83,5396 & & & & $\begin{array}{c}15,1 \\
4\end{array}$ & \\
\hline \multirow[t]{2}{*}{3.} & \multirow[t]{2}{*}{ Castana } & \multirow[t]{2}{*}{784} & $\begin{array}{c}- \\
11,1\end{array}$ & \multirow{2}{*}{$\begin{array}{c}124,099 \\
6\end{array}$} & 17. & $\begin{array}{l}\text { Risqy } \\
\text { Langit }\end{array}$ & 1156 & $\begin{array}{c}- \\
5,14\end{array}$ & 26,4196 \\
\hline & & & 4 & & \multirow[t]{3}{*}{18.} & Tias & & & \\
\hline 4. & Chamelia & 1936 & 4,86 & 23,6196 & & Ramadha & 900 & & 83,5396 \\
\hline \multirow[t]{2}{*}{5.} & Dian & \multirow{2}{*}{1936} & \multirow{2}{*}{4,86} & \multirow{2}{*}{23,6196} & & ni & & & \\
\hline & Lestari & & & & \multirow[t]{2}{*}{19.} & \multirow[t]{2}{*}{ Tukiman } & \multirow{2}{*}{1024} & - & 500706 \\
\hline \multirow[t]{2}{*}{6.} & Dini & \multirow[b]{2}{*}{2704} & \multirow{2}{*}{$\begin{array}{c}12,8 \\
6\end{array}$} & \multirow{2}{*}{$\begin{array}{c}165,379 \\
6\end{array}$} & & & & 7,14 & \\
\hline & $\begin{array}{l}\text { Ramdani } \\
\text { Oktiawati }\end{array}$ & & & & 20. & $\begin{array}{l}\text { Vika } \\
\text { Lestari }\end{array}$ & 1296 & $\begin{array}{c}- \\
3,14\end{array}$ & 9,8596 \\
\hline 7. & Fitriyani & 1024 & $\begin{array}{c}- \\
7,14\end{array}$ & 50,9796 & 21. & $\begin{array}{l}\text { Zahra } \\
\text { Rifatul }\end{array}$ & 1156 & & 26,4196 \\
\hline 8. & Khaerul & 1 & 0 & & & Istiqna & & & \\
\hline & Sobirin & 1000 & 0,00 & טים & & $\mathrm{N}=21$ & 3379 & 0,06 & 1620,57 \\
\hline 9. & Kiswah & 3364 & 18,8 & 355,699 & & & 6 & & 2 \\
\hline
\end{tabular}

\begin{tabular}{|c|lcc|c|} 
& Azizah & 3364 & 6 & 6 \\
\hline 10. & Kristina & 1936 & 4,86 & 23,6196 \\
\hline 11. & $\begin{array}{l}\text { Lusi } \\
\text { Indriyani }\end{array}$ & 2304 & 8,86 & 78,4996 \\
\hline 12. & $\begin{array}{l}\text { Meli } \\
\text { Ratnawat } \\
\text { i }\end{array}$ & 1764 & 2,86 & 8,1796 \\
\hline 13. & $\begin{array}{l}\text { Nani } \\
\text { Mealifah }\end{array}$ & 1600 & 0,86 & 0,7396 \\
\hline
\end{tabular}

Pada tabel di atas berhasil diperoleh:

$\sum \mathrm{d}=822$

$\sum \mathrm{d}^{2}=33796$

$\sum \mathrm{Xd}=0,06$

$\sum \mathrm{Xd}^{2}=1620,572$

Rumus menghitung uji $t$ untuk mengetahui efektivitas pembelajaran dengan satu kelompok sampel sebagai berikut. 


$$
\mathrm{t}_{0}=\frac{M d}{\sqrt{\frac{\sum X d^{2}}{N(N-1)}}}
$$

a) Mencari rata-rata (mean) dari deviasi $(d)$ antara post-test dan pre-test

$$
\begin{aligned}
\text { Md } & =\frac{\sum d}{21} \\
& =\frac{822}{21} \\
& =39,14
\end{aligned}
$$

b) Diketahui $\sum \mathrm{Xd}^{2}=1620,572$

c) Diketahui $\mathrm{N}=21$

d) Mencari df atau db

$$
\begin{aligned}
\mathrm{df} & =\mathrm{N}-1 \\
& =21-1 \\
& =20
\end{aligned}
$$

e) Mencari $\mathrm{t}_{0}(t$ hitung)

$$
\begin{aligned}
\mathrm{t}_{0} & =\frac{\boldsymbol{M d}}{\sqrt{\frac{\sum \boldsymbol{X d ^ { 2 }}}{N(\boldsymbol{N - 1})}}} \\
& =\frac{39,14}{\sqrt{\frac{1620,572}{21(21-1)}}} \\
& =\frac{39,14}{\sqrt{\frac{1620,572}{420}}} \\
& =\frac{39,14}{\sqrt{3,85}} \\
& =\frac{39,14}{1,96} \\
& =19,96
\end{aligned}
$$

f) Kriteria pengambilan keputusan

Terima $\mathrm{H}_{0}$ jika $\mathrm{t}_{0} \leq \mathrm{t}_{\text {tabel }}$

Tolak $\mathrm{H}_{0}$ jika $\mathrm{t}_{0}>\mathrm{t}_{\text {tabel }}$

Taraf signifikan $\alpha=0,05$

$\mathrm{t}_{\text {tabel }}=\mathrm{t}_{(0,05 ; 20)}=1,725$
Hipotesis alternatif $\left(\mathrm{H}_{\mathrm{a}}\right)$ menyatakan bahwa pembelajaran berbicara teks narasi dengan menggunakan metode partisipatori berbasis kecerdasan kinestetik di kelas VII akan efektif. Sedangkan hipotesis nihil $\left(\mathrm{H}_{0}\right)$ menyatakan bahwa pembelajaran berbicara teks narasi dengan menggunakan metode partisipatori berbasis kecerdasan kinestetik di kelas VII tidak efektif. Karena $t_{0}>t_{\text {tabel }}$ maka tolak $\mathrm{H}_{0}(19,96>1,725)$. Dengan demikian pembelajaran berbicara teks narasi dengan menggunakan metode partisipatori berbasis kecerdasan kinestetik di kelas VII SMP Negeri 3 Sindang tahun pelajaran 2018/2019 efektif.

\section{SIMPULAN}

\section{Simpulan}

Hasil pengkajian data penelitian yang telah dipaparkan pada Bab IV mengenai efektivitas pembelajaran berbicara teks narasi dengan metode partisipatori berbasis kecerdasan kinestetik di kelas VII SMP Negeri 3 Sindang tahun pelajaran 2018/2019 dapat ditarik simpulan sebagai berikut.

1) Kemampuan siswa kelas VII SMP Negeri

3 Sindang tahun pelajaran 2018/2019 dalam berbicara teks narasi sebelum mengikuti pembelajaran masuk dalam kategori gagal. Hal ini terlihat dari nilai rata-rata sebesar 38,28 . Nilai rata-rata ini masuk dalam kategori gagal karena siswa 
belum mampu menceritakan kembali isi cerita rakyat (legenda) yang dibaca dengan benar.

2) Kemampuan siswa kelas VII SMP Negeri 3 Sindang tahun pelajaran 2018/2019 dalam berbicara teks narasi sesudah mengikuti pembelajaran masuk dalam kategori baik. Hal ini terlihat dari nilai rata-rata sebesar 77,42. Nilai rata-rata ini masuk dalam kategori baik karena hampir semua siswa mencapai ketiga tujuan pembelajaran dengan baik. Siswa mampu mencermati cerita rakyat (legenda) yang berasal dari daerah setempat dengan benar, mampu berlatih menceritakan isi cerita rakyat (legenda) yang dibaca dengan benar, dan mampu menceritakan kembali isi cerita rakyat (legenda) yang dibaca dengan benar.

3) Pembelajaran berbicara teks narasi dengan metode partisipatori berbasis kecerdasan kinestetik di kelas VII SMP Negeri 3 Sindang tahun pelajaran 2018/2019 efektif. Hal ini terlihat dari $t_{\text {hitung }}$ sebesar 19,96 sedangkan menurut $t_{\text {tabel }}$ dengan taraf signifikan 0,05 diperoleh $1,725\left(\mathrm{t}_{\text {tabel }}=\mathrm{t}_{(0,05 ; 20)}=1,725\right)$. Jadi dapat ditarik simpulan, $\mathrm{t}_{0}>\mathrm{t}_{\text {tabel }}$ maka tolak $\mathrm{H}_{0}(19,96>1,725)$. Selisih rata-rata pre-test dan post-test sebesar 39,14 setelah dihitung dengan uji-t hasilnya signifikan, hal ini berarti pembelajaran berbicara teks narasi dengan metode partisipatori berbasis kecerdasan kinestetik efektif.

\section{Saran}

Berdasarkan simpulan di atas, dapat dirumuskan saran sebagai berikut.

1. Guru mata pelajaran Bahasa Indonesia dapat menggunakan metode partisipatori berbasis kecerdasan kinestetik, merupakan metode pembelajaran yang menarik dalam mata pelajaran Bahasa Indonesia. Dengan demikian, siswa lebih termotivasi untuk belajar dan meningkatkan prestasi belajarnya.

2. Guru mata pelajaran Bahasa Indonesia dapat menggunakan metode partisipatori berbasis kecerdasan kinestetik dalam pembelajaran berbicara teks narasi, karena metode ini terbukti efektif dalam pembelajaran berbicara teks narasi di kelas VII SMP Negeri 3 Sindang Tahun Pelajaran 2018/2019.

3. Guru mata pelajaran Bahasa Indonesia sebaiknya dapat menciptakan variasi pembelajaran yang kreatif dan menyenangkan agar dapat menarik semangat siswa sehingga suasana kelas lebih kondusif dan diharapkan dapat ditetapkan pada materi pelajaran yang lain.

4. Penggunaan metode partisipatori berbasis kecerdasan kinestetik dapat dijadikan sebagai strategi dalam 
pembelajaran Bahasa Indonesia pada sekolah yang dapat memotivasi belajar dan sebagai salah satu alternatif untuk meningkatkan mutu pembelajaran.

5. Dengan adanya inovasi metode pembelajaran di sekolah diharapkan dapat meningkatkan mutu belajar siswa.

\section{DAFTAR PUSTAKA}

Amstrong, T. (2002). 7 Kinds of smart: menemukan dan meningkatkan kecerdasan dan anda berdasarkan teori multipl intelligence. Jakarta: Garamedia Pustaka Utama.

Amstrong, T. (2009). Multilpe Intelligences in The Classroom. Virginia: ASCD.

Depdiknas. (2007). Kamus Besar Bahasa Indonesia. Jakarta: Balai Pustaka.

Franekel, J.R.\& Wallen, N.R. (2012). How to design and evaluate research in education. New York: The McGraw-Hill Companies.

Iskandarwssid \& Sunendar, D. (2008). Strategi Pembelajaran Bahasa. Bandung: UPI dengan PT Remaja Rosdakarya.

Kerap, G. (1997). Terampil Berbahasa Indonesia 2. Jakarta: Balai Pustaka.

Nurgiyantoro, B. (1995). Penilaian dalam Pengajaran Bahasa dan Sastra Indonesia. Yogyakarta: BPFE.

Nurgiyantoro, B. (2007). Teori Pengkajian Fiksi. Yogyakarta: Gadjah mada University Press.

Majid, A. (2001). Mendidik dengan Cerita. Bandung: Rosdakarya.
Pidarta, M. (2005). Perencanaan Pendidikan Partisipatori dengan Pendekatan Sistem. Jakarta: PT Rineka Cipta.

Pramesti,G. (2004). Kupas Tuntas Data Penelitian Dengan SPSS 22. Jakarta: PT Elex Media Komputindo Kompas Garamedia.

Semi, M.A. (1988). Anatomi Sastra. Padang: Angkasa Raya.

Sudjana. (2005). Metode dan Teknik Pembelajaran Partisipatif. Bandung: Falah Production.

Sudjiman. (1984). Kamus Istilah Sastra. Jakarta: Garamedia.

Sugiyono. (2005). Metode Penelitian Kualitatif. Bandung Alfabeta.

Sugiyono. (2010). Metode Penelitian Kuantitatif Kualitatif dan RND. Bandung: Alfabeta.

Sugiyono. (2012). Metode Penelitian Pendidikan. Bandung: CV Alfabeta.

Sumardjo, J. (1980). Seluk Beluk Cerpen. Bandung: Mitra Kencana.

Suparno \& Yunus, M. (2009). Keterampilan Dasar Menulis. Jakarta: Universitas Terbuka.

Tarigan, H.G. (2008). Berbicara. Bandung: Angkasa.

Tarigan, H.G. (2008). Membaca Sebagai Suatu Keterampilan Berbahasa. Bandung: Angkasa.

Tarigan, D \& Tarigan, H.G. (1987). Teknik Pengajaran Keterampilan Berbahasa. Bandung: Angkasa.

Tompkins, G.E. \& Kenneth, H. (1991). Language Art Content And Teaching Strategies. New York: mac Millan. 